\title{
Investigate Report for Undergraduate of Credit Management
}

\author{
Yu-Han WANG \\ School of Economics \& Management \\ Shanghai Polytechnic University \\ Shanghai, China \\ E-mail:hylandwang@126.com
}

\author{
Shi-Wen SHANG \\ School of Economics \& Management \\ Shanghai Polytechnic University \\ Shanghai, China \\ E-mail:qiyiguo2@126.com
}

\begin{abstract}
The promotion of China's social credit system construction work, credit management system being standardized, and various types of credit information platforms being constructedhas caused the demand for credit management professionals will increase. Talents credit management will also draw more attention. The paper is based on the undergraduate of credit management's surveys. Analysis of the characteristics in terms of training objectives, abilities, knowledge, skills training and overall quality, etc. This paper is intended to provide certain information support for credit management personnel training purposes.
\end{abstract}

Keywords-Undergraduate of credit management, Professional Training, Research

Credit management professional work is divided into two categories. One is "Second party credit management", and the other is "Third party credit service". There is no difference in the nature of professional skills required.

The second party credit management mainly refers to the credit management department, the risk management department and other related posts."Credit management" related services for such companies and institutions are mainly for developing internal businesses, reducing risk, and the implementation of risk management services. The second party credit management mainly includes: stateowned commercial banks, joint-stock banks, securities companies, insurance companies, large and medium-sized manufacturing enterprises of the internal related departments and departments.

Third party credit service is mainly used in the market to provide credit management related services and products, such as credit rating, and consulting as the main business of the unit. In accordance with the principle of commercial competition in the market, in the society, businesses pay to provide all kinds of objectives, independent credit investigation report, credit rating report, advisory reports and other credit services products.

Whether "second" or "third party" background is due to information asymmetry inherent in the market economy, the need to expand the credit investigation, assessment, reporting, consulting, risk control, security or other types of credit management of special work is unclear. However, the two focus and specific methods of operation, operation technology and experience will be significantly different, so the requirements of professional training colleges should also have different characteristics.

\section{SURVEYONGENERAL SITUATION}

Shanghai Second Polytechnic University's credit management undergraduate since 2005 has officially enrolled six graduates, a total of nearly 500 students to the market. After ten years of personnel training. In the second half of 2015, we complete a credit management undergraduate training market research.

\section{A. Research Objects and Methods}

The object and method of this research include:

TABLE I. RESEARCH METHODS

\begin{tabular}{|l|l|}
\hline Research object & Research methods \\
\hline $\begin{array}{l}\text { Government departments } \\
\text { and industry associations }\end{array}$ & $\begin{array}{l}\text { Survey, questionnaire } \\
\text { and telephone } \\
\text { interview }\end{array}$ \\
\hline Companies and institutions & $\begin{array}{l}\text { Questionnaire survey } \\
\text { and field interview }\end{array}$ \\
\hline Fraternal institutions & $\begin{array}{l}\text { Questionnaire survey, } \\
\text { online data collection, } \\
\text { face-to-face interview }\end{array}$ \\
\hline Graduate & $\begin{array}{l}\text { Telephone interviews, } \\
\text { seminars, individual } \\
\text { questionnaires }\end{array}$ \\
\hline Students & $\begin{array}{l}\text { Telephone interviews } \\
\text { and seminars }\end{array}$ \\
\hline
\end{tabular}

In table 1 and table 2, a view of the national institutions colleges with similar professional research, using it as a guideline for our questionnaire. Taking into account the purpose of the survey is to fully understand the credit management of emerging undergraduate professional training and the existence of credit management activities. The investigation team will lead the country into opening credit management professional colleges and universities to carry out research.

\section{B. The Division of the Level of Talent Cultivation in Credit Management}

- On the training level analysis, the current national university to complete the master and doctor, each stage of the cultivation of university include: Renmin University of China, Shanghai University of Finance and Economics etc... Taking Shanghai University of Finance and Economics and Renmin University of China as an example, the main 
purpose is to send students in each stage of the credit management of banks and other financial institutions. These kind of colleges and universities has formed the cooperative development opportunities of credit management discipline and specialty.

- Some colleges and universities only complete the master, doctor stage training. Taking Southwestern University of Finance and Economics as an example, they only train master of credit management. Doctor is only a development direction at this current time. Their professional training and discipline research are linked relatively and closely.

- A considerable part of the credit management professional colleges and universities is that the personnel training is only limited to the undergraduate level.In this part of the University, the current situation is more than the credit management professional positioning not achieving cohesion.Taking Shanghai Normal University as an example, the personnel training by "enrollment" mode for "credit management" training development direction is still in progress, but we must keep in mind that because of its large class enrollment, the development in the end will to be a blowout.

- Vocational colleges are not included in the survey analysis.

Brief summary of the various colleges and universities "credit management" professional situation and characteristics of the school as shown in table 3.

In our investigation, a total of 20 from the country with a credit management professional colleges and universities issued a total of 30 questionnaires. There are 24 effective questionnaires collected from 12 undergraduate students majoring in credit management. The objective of the questionnaire is to learn more about credit management professions.

Some colleges and universities intend to carry out the investigation and analysis of the situation of credit management personnel training in different universities. This is to understand the orientation and characteristics of the cultivation of undergraduate talents in credit management. Then, we can make reasonable demands to the knowledge and ability structure and quality standard of undergraduate talents of credit management and to provide the basis for the application of credit management undergraduate education in this investigation.

\section{INVESTIGATION AND ANALYSIS}

In this investigation, we know that:

\section{A. The Goal of Talent Cultivation of Credit Management in Universities}

The goal of talent training in most colleges and universities:

Cultivate the political quality and moral good, honest and trustworthy, to adapt to the construction of credit system in China, have a solid foundation of knowledge, innovative spirit and practical ability to all types of enterprises, financial institutions and social intermediary organizations and government agencies from the application about credit analysis and management of senior innovative talents.

The personnel training orientation and characteristics of the credit management specialty of the investigation unit are divided into the following seven types:

- Credit evaluation and risk management professionals

- Applied and international enterprise credit management professionals

- Credit management professionals for financial institutions

- The market demand oriented application, complex credit management personnel

- Enterprise oriented credit management professionals

- Proficient in foreign language credit management talent

Credit guarantee and small and micro enterprise credit management professionals.

\section{B. The Choice of Employment Orientation of College} Graduates Majoring in Credit Management

As seen in figure 1, the University of Credit Management Graduates choose the top three jobs: commercial banks and other financial institutions, large and medium enterprises, and intermediaries.

\section{The Personnel Training Program and the}

Establishment of the Specialized Courses of the Credit Management Specialty in Colleges and Universities

According to the training goal of colleges and universities design program summary and research results, the university had more than $80 \%$ courses including: Introduction to Credit Management, Management, Accounting, Econometrics, Statistics, Financial Analysis, Credit Technology Foundation, Credit Rating, Credit Risk Management, Financial Management, Finance, Commercial Bank Management Courses and so on.

Consumer Credit Management, Enterprises Credit Management, Bank and Enterprises Credit Management, Enterprise and Personal Credit Management, Credit Information Collection, Data Collection and Analysis of Credit Management, Credit Card Business Management, Credit Management, Investment, Financial Supervision are obvious in individuality and need to all be acquired.

\section{The Main Professional Knowledge and Skills of the Students Majoring in Credit Management}

In Figure 2, all colleges and universities pay attention to the development of credit management students in mastering the main professional knowledge and skills. Such as Financial, Credit Rating, Risk Management, Credit Investigation and Statistical Analysis. Financial knowledge and statistical analysis of relevant knowledge is the basic knowledge of credit management and it's essential for developing comprehensive talents. Credit Management, Credit Risk Management and Credit Rating Knowledge are the 3 core knowledge components.

\section{E. The Comprehensive Ability of the Credit}

\section{Professionals in the Universities Under Investigation}

In Figure 3, the comprehensive ability of measuring weight training of credit management professionals in Colleges and universities are the main analytical problem 
solving skills, learning ability, teamwork ability and communication ability. The training methods are mainly social practice and training platform for simulation experiment, school enterprise cooperation, and banks and other financial institutions jointly launched the actual operation experiment, through daily teaching, the development of creative abilities in students etc..

F. Investigation on the Requirements of the Professional Qualification for the Cultivation of the Students Majoring in Credit Management in Colleges and Universities

In figure 4 you can see that only a few schools for students in the credit management occupation qualification requirements, a great part of the school without occupation certificate requirements, but most of the teachers think credit management professional students should obtain some related certificates, such as accounting certificate, CPA, CFA, credit management division the bank and the securities qualification certificate, and qualification certificate. The passing rate of the accounting certificate, bank securities qualification certificate, qualification certificate is relatively high, and the rest is relatively low.

\section{G. Talent Training Mode and Effect of School Enterprise Cooperation}

\section{1) The school enterprise cooperation mode}

- Professionals in the industry to carry out professional courses, and organize students to cooperative enterprise internship;

- Set up the internship base, with the bank to arrange internships, jointly organized a variety of activities;

- Cooperate with enterprises and banks, use the holiday to organize the internship or ask the senior management to report to the school;

- Extensive cooperation with rating agencies, small loan institutions, credit agencies

- Winter and summer vacation to carry out social practice, corporate executives to school lectures, hired as a visiting professor.

2) Evaluation on the effect of school enterprise cooperation in the schools under investigation

- Through the operation of learning hands on, the students' practical ability is improved, the barriers to entry into the industry are reduced, and the employment rate is increased;

- With the school enterprise cooperation, organizing the students to the enterprise practice, the student response is good, the effect is good;

- Still exploring a more effective mode of school enterprise cooperation;

- Unsystematic school enterprise cooperation.

H. Evaluation of the Importance of Credit Management in Shanghai Second Polytechnic University Courses Offered

Figure 5 told us:

- The unit being investigated recognized our school credit management. In addition to differences in the Credit Law, Credit Insurance and Securities
Investment to set up courses is necessary or not. Other courses are considered very important or important;

- The investigation of credit management in Colleges and universities to set up courses and our school basically the same, but there are some different ones.(as mentioned above);

- Some colleges and universities do not set up the courses about Credit Insurance, Credit Management and Credit Law;

- The other colleges and universities set up the Credit Guarantee, Operations Research, Credit Cards and Financial Supervision and other courses;

Some colleges and universities that take into account the characteristics of credit management and finance disciplines, the need to pay more attention to the creation of financial courses.

\section{The Importance of Evaluation of the Credit} Management Practice Course in Shanghai Second Polytechnic University

- $45.83 \%$ of the schools believe that professional practice (including professional introduction, accounting, computer, economics and other aspects of practical skills training) is very important, there are more than $37.5 \%$ of the schools that believe the course is more important;

- There are $66.67 \%$ schools of thought based professional practice (including the training of practical skills, statistical data analysis, finance, marketing and so on) is very important, there are $16.67 \%$ schools that believe this course is more important;

- There are $66.67 \%$ schools of thought credit management professional comprehensive ability of practice (including credit investigation, credit rating, credit management, credit report and other aspects of the practical skills training) is very important, there are $12.5 \%$ schools that believe this course is more important.

J. Investigate about the Necessary or Not on Subdivide the Professional Direction of Credit Management in Shanghai Second Polytechnic University

Professional subdivision is a double-edged sword, it can really allow students to conduct in-depth study of the subject. Although every field has its master, it may be limited to the scope of knowledge and employment, etc..

$20.83 \%$ of the units surveyed believe that our students should be divided into professional direction, the main reasons include the following two points:

- Reflecting the construction of professional characteristics, such as government credit, corporate credit, social credit, consumer credit, bank credit, etc..

- Distinguish between the professional direction so that students can clear the relationship between the professional and the market, it is easier to follow the professional direction, to strengthen the training of professional skills, to better adapt to market demand for professionals.

$70.83 \%$ of the units surveyed believe that our students should not be trained in the direction of professional 
credit management, the main reason is that:

- Credit management itself is already a third-level discipline, if we continue to subdivide discipline too much, the course will be cross and scope of knowledge will be narrow, knowledge structure system will not complete, the training plan will not easy to operate;

- We can open more elective courses, elective courses in the appropriate directional focus, in order to allow students to choose courses. On the other hand, it will respect for the students' personality and the right of independent choice also provide a certain channel for further study;

- In the field of credit management, fewer the number of teaching materials, more limited the demand for talents, less form the market scale and less clear the development situation, then premature subdivision of the direction may be out of touch with the needs of the talent market;

- Less employment choice cannot fit the current social demand for credit management personnel;

- Around the financial industry, business, trade development is different, the lower the degree of financial development in the region, and then set the direction of specialized credit management professional's demand is certainly limited.

K. This Paper Takes "Enterprise Credit Management" as the Characteristics of Talent Cultivation, and Puts forward Some Suggestions on the Cultivation of Professional Talents, Curriculum and Knowledge Arrangement

General professional courses (including practical courses)

General professional courses should focus on the popularization of knowledge, pay attention to the improvement of the level of basic knowledge. The curriculum can be carried out from the following three aspects:

- Credit management courses: Credit Rating, Credit Model Building, Credit Management, Corporate Credit Management, Consumer Credit Management, Debt Collection, Credit Risk Management;

- Fundamentals of financial management: Principles of Accounting, Financial Statement Analysis;
- Basic courses in Economics: Economics, Finance, Management, Marketing, International Settlement,

Econometrics, Securities Investment.

Specialty courses (including practical courses):

The characteristics of professional courses should focus on professional quality, professional ability, highlighting the characteristics, which specialized in the ability for the school to reform, can from the following two aspects:

Professional basic courses: Enterprise Credit Management, Credit Technology, Credit Rating, Credit Risk Analysis and Measurement, Financial Institutions Credit Management, Management Science;

Practical courses: Cases of Enterprise Credit Management, Case of Debt Collection, and case study of enterprise credit management, corporate finance (Accounting) practice, credit rating agencies and credit rating agencies.

To sum up, through the investigation and research we see that similar majors in Colleges and universities have little to no difference. For most of the open credit management undergraduate colleges, they realize professional orientation, and training objectives of differential culture, through the clear characteristics of personnel training and accurate training objectives for positioning, highlighting the characteristics of credit management in their own school. This is the only way to successfully and sustainably development under the contradiction between that less knowledge about credit management in our society and more demand on industry and profession.

\section{ACKNOWLEDGMENTS}

Thanks to my school for supporting this paper. Project grant No.xxkpy1602.Project funding: Finance of training department

\section{REFERENCES}

[1] X.R. YE \& TANG M.Q. \& GUO J.L., The transformation of vocational education and curriculum reform in undergraduate colleges and Universities -- a case study of credit management specialty [J]. Financial Teaching and research, 2014, (3): 7073.(in Chinese)

[2] WANG H.L. \& Z.H. HAO. "The urgency of training the talents of credit management" [J]. Vocational education research, 2014, (3): 127-128. (In Chinese)

TABLE II. COLLEGES AND UNIVERSITIES WITH CREDIT MANAGEMENT[1]

\begin{tabular}{|c|c|}
\hline Enrollment year & Universities and Colleges \\
\hline 2002 & Shanghai University of Finance and Economics;Renmin University of China \\
\hline 2003 & Jilin University \\
\hline 2005 & Shanghai Polytechnic University; Shanghai Lixin University Of Commerce \\
\hline 2006 & Shanghai Finance University \\
\hline 2007 & Nanjing Audit University; Zhejiang University Of Finance \& Economics \\
\hline 2008 & Shandong University of Finance and Economics \\
\hline 2009 & Tianjin University Of Finance \& Economics \\
\hline \multirow{3}{*}{2010} & Tianjin University Of Commerce; Shanghai Normal University \\
\hline & $\begin{array}{l}\text { Guangdong University Of Finance;Rongzhi College of Chongqing Technology And } \\
\text { Business University }\end{array}$ \\
\hline & LanZhou University of Finance and Economics \\
\hline 2012 & $\begin{array}{l}\text { Harbin University Of Finance; Hubei University Of Economics; Longqiao College of } \\
\text { Lanzhou Commercial College }\end{array}$ \\
\hline
\end{tabular}




\begin{tabular}{|l|l|}
\hline \multirow{2}{*}{2013} & $\begin{array}{l}\text { Tianjin University of Technology and Education; Henan University of Economics and } \\
\text { Law; }\end{array}$ \\
\cline { 2 - 2 } & Zhuhai Campus; Beijing Institute of Technology \\
\hline 2014 & Nanjing University Of Finance \& Economics; Xi'an International Studies University \\
\hline 2016 & Southwestern University Of Finance And Economics \\
\hline
\end{tabular}

TABLE III. THE GENERAL SITUATION OF THE PROFESSIONAL TRAINING OF CREDIT MANAGEMENT IN REPRESENTATIVE UNIVERSITIES

\begin{tabular}{|c|c|c|c|}
\hline category & Representative University & Characteristic & Orientation and direction of talents \\
\hline $\begin{array}{l}\text { 985, } 211 \text { types } \\
\text { of Academic } \\
\text { Universities }\end{array}$ & $\begin{array}{l}\text { Shanghai University of Finance and } \\
\text { Economics; } \\
\text { Renmin University of China }\end{array}$ & $\begin{array}{l}\text { 1.Completion of Personnel training } \\
\text { level } \\
\text { 2.Relying on its influence in the } \\
\text { economic and management field, } \\
\text { reputation in the financial industry } \\
\text { and the reputation of the school } \\
\text { brand radiation }\end{array}$ & $\begin{array}{l}\text { 1.Theoretical research talents } \\
\text { 2.Financial institutions risk control, } \\
\text { credit management and related technical } \\
\text { personnel } \\
\text { 3. Others (including teachers, } \\
\text { government departments, etc.) }\end{array}$ \\
\hline $\begin{array}{l}\text { 985, } 211 \text { types } \\
\text { of Academic } \\
\text { Universities, } \\
\text { Other parts of } \\
\text { the application } \\
\text { of colleges and } \\
\text { Universities }\end{array}$ & $\begin{array}{l}\text { Southwestern University Of Finance } \\
\text { And Economics(only Master level) } \\
\text { Tianjin University Of Finance \& } \\
\text { Economics(only the direction of } \\
\text { Master and Doctor) }\end{array}$ & $\begin{array}{l}\text { 1.Ability to train postgraduate } \\
\text { 2.clear characteristics of running a } \\
\text { school }\end{array}$ & $\begin{array}{l}\text { 1.Theoretical research talents } \\
\text { 2.Financial institutions management } \\
\text { personnel (not necessarily completely } \\
\text { related to the professional) } \\
\text { 3.Credit rating agencies (willing to go, } \\
\text { but not a lot of opportunities) }\end{array}$ \\
\hline $\begin{array}{l}\text { Applied } \\
\text { Undergraduate } \\
\text { Colleges }\end{array}$ & $\begin{array}{l}\text { Shanghai Polytechnic University; } \\
\text { Shanghai Finance } \\
\text { Guangdong University; } \\
\text { Hubei University Of Of Finance; } \\
\text { Rongzhi College of Chonomics; } \\
\text { Technology And Business University } \\
\ldots\end{array}$ & $\begin{array}{l}\text { Only undergraduate level } \\
\text { each has the characteristic of running } \\
\text { a school, or launches the compound } \\
\text { talented person raise } \\
\text { Based on the whole country, serving } \\
\text { the local economy }\end{array}$ & $\begin{array}{l}\text { 1.Applied talents training } \\
\text { 2.Intermediary agency(Access to credit } \\
\text { rating agencies is difficult) } \\
\text { 3.Financial institutions (cannot directly } \\
\text { engaged in professional work) } \\
\text { 4.companies }\end{array}$ \\
\hline
\end{tabular}

\section{Graduate employment choice}

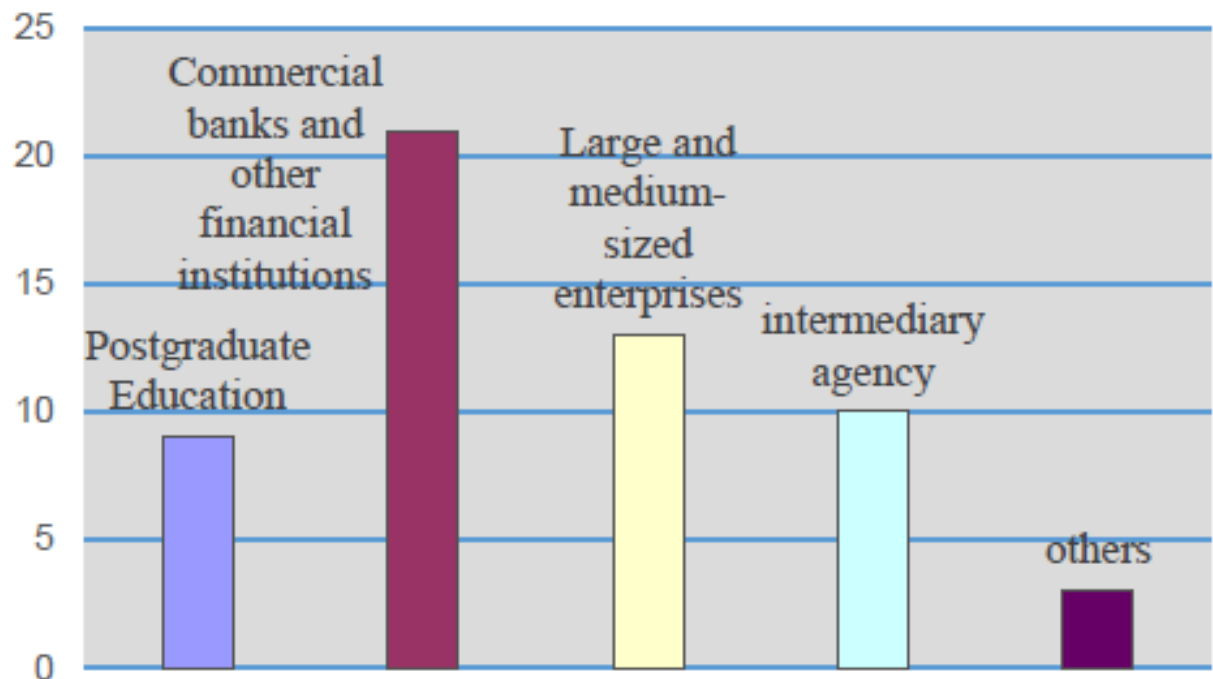

Figure 1. Graduate employment choice 


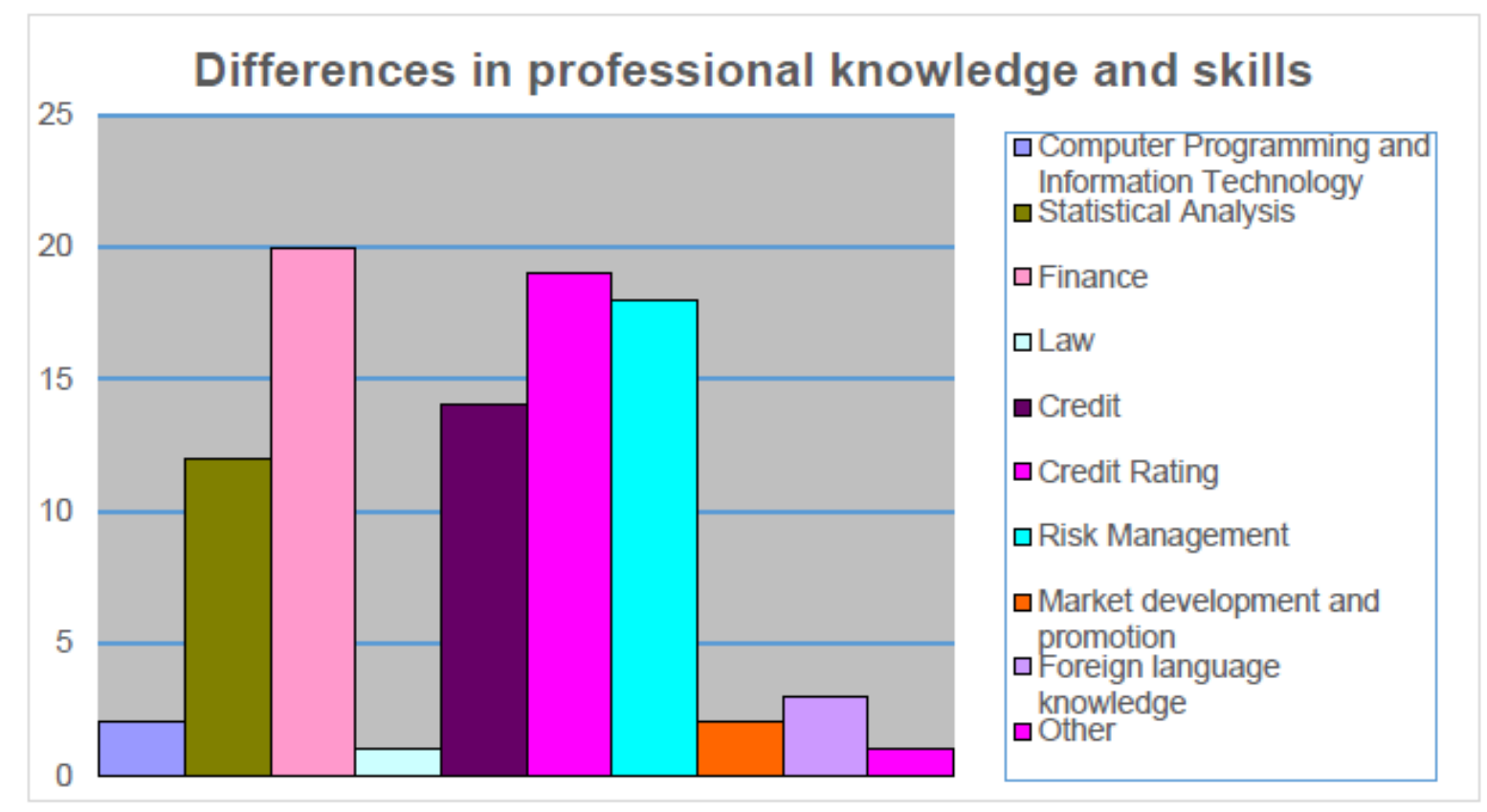

Figure 2. Professional knowledge and skills in personnel training

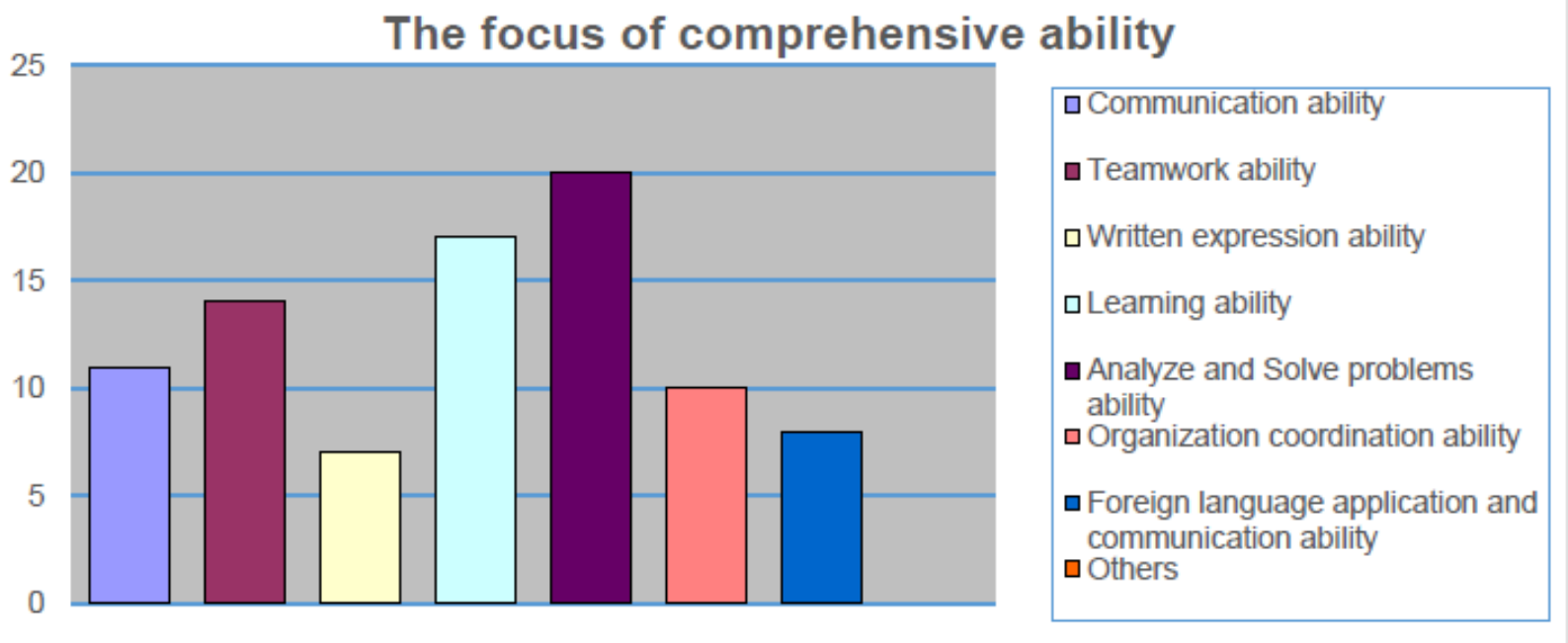

Figure 3 Comprehensive ability of credit professionals

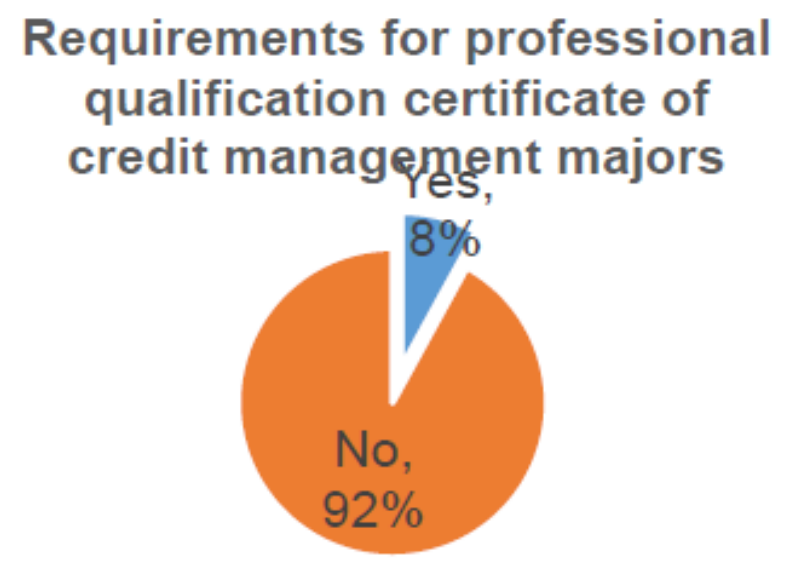

Figure 4. Comprehensive ability of credit management professionals 


\section{Importance of curriculum}

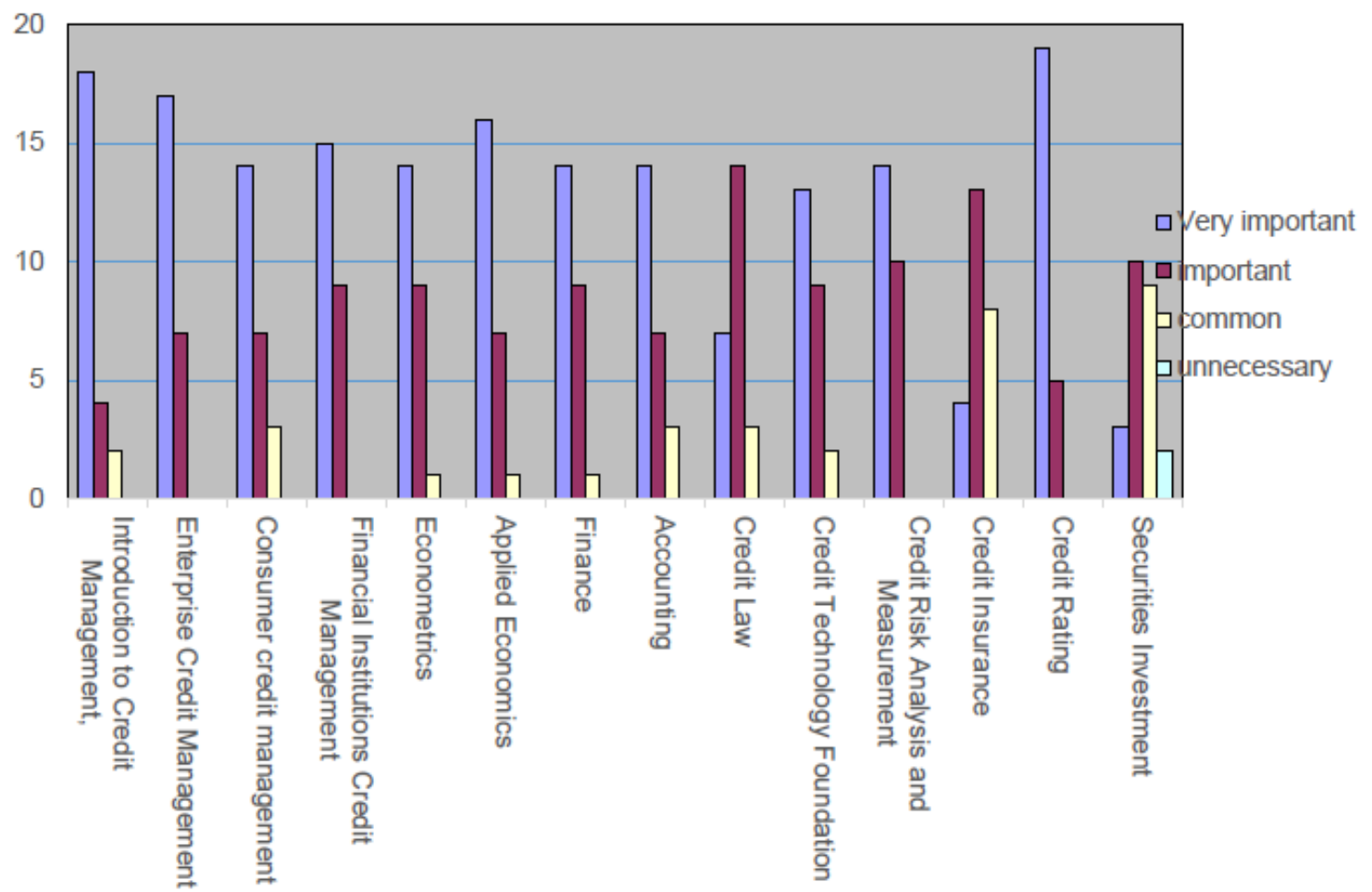

Figure 5. the recognition of the professional courses offered by the investigation unit to our credit management 